\title{
Artistic Citizenship: Escaping the Violence of the Normative (?)
}

\section{Deborah Bradley}

This article offers a critique of the concept of artistic citizenship, focusing on citizenship as it relates to the institutions of state and nationhood. I explore the tensions between metaphorical concepts of citizenship employed in the work of various authors (Campbell and Martin 2006; Downey 2014; Elliott, Silverman, and Bowman 2016), and citizenship as the institution related to state/nationhood (Brandzel 2016) with its potential for negative normativity. Questions emerging from this exploration focus on what the terminology of artistic citizenship might mean for those vulnerable to the machinations of the state, those without citizenship such as the "Dreamers," or those who are stateless.

Keywords: citizenship, artistic citizenship, artivism, social responsibility, nationalism, normativity

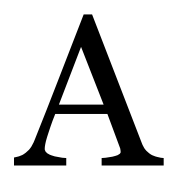

great deal has been written recently on the concept of artistic citizenship; the recent book, Artistic Citizenship: Artistry, Social Responsibility, and Ethical Praxis (Elliott, Silverman, and Bowman 2016) joins other similar publications, including Artistic Citizenship: A Public Voice for the Arts (Campbell and Martin 2006), and Art and Politics Now (Downey 2014). Explorations on the topic extend into the role of the legal field in artistic activism such as Unlikely Muse: Legal Thinking and Artistic Imagination (Kornstein 2010). In the Elliott et al. and Campbell \& Martin books, the concept of artistic citizenship is unhinged from its associations with state and nationhood, invoked as a metaphor to allow for "evocative," open interpretation (Elliott, Silverman, and Bowman 2016, 7) related to artistry undertaken in the name of social responsibility. In the Downey and Kornstein books, the relationship between artistic activism and nationhood is treated as sometimes yes, sometimes no. In recent music education research, Juliet Hess conducted a study with several self-identified "activist musicians" (Hess 2018), in which she concluded that socially responsible activist musicians in the

(C) Deborah Bradley 2018. The content of this article is the sole responsibility of the author. The ACT Journal and the Mayday Group are not liable for any legal actions that may arise involving the article's content, including, but not limited to, copyright infringement. 
music class have the ability to "challenge dominant understandings of who can engage in music." Indeed, this notion of challenging the status quo through one's artistic endeavors threads throughout all the literature on artistic citizenship.

This paper, however, explores the concept of artistic citizenship and its relationship to social responsibility from the perspectives drawn from another recent publication, Against Citizenship: The Violence of the Normative by Amy Brandzel (2016). Brandzel utilizes case studies to support a definition of citizenship tied to one's ability to be "admitted" to the status of citizen within the institutions of state or nationhood, and it is from this perspective that I also critique the concept of citizenship as it may be utilized in arts education. One case study in Brandzel's book focused on the normativity of same sex marriage, another on the loss of sovereignty experienced by Native Hawaiians once the islands of Hawaii were "granted" U.S. statehood. In juxtaposing the metaphorical and nationalistic meanings of the term citizenship, I seek to untangle some of the questions that emerge from the notion of citizenship and its propensity for application as a normative and potentially violent concept. I explore the negative normativity of citizenship-in both metaphorical and legal senses-in part because of the increased potential for normative and negative applications of the concept since Donald J. Trump became the U.S. president, and emerging from his frequent verbal threats to the freedoms that Americans have taken for granted for over 200 years, but also because of the recent interest in educational disciplines related to the concept of artistic citizenship. What is it about this term that has such appeal? Metaphorical notions of citizenship often conflict with the legal meanings of the term, and although that conflict holds potential to yield rich and nuanced discussion, the education field's tendency toward jargon often subsumes such rich and nuanced concepts into "eduspeak" (Willen 2013)-watered-down versions of their original robust meanings. Assuming that artistic citizenship represents a set of values that are both desirable and teachable, are the desirable values perhaps better described in other ways? As Elliot et al. ask, "what does 'citizenship' mean, and how might these meanings relate to our understandings of the privileges and obligations that attend artistic practices" (Elliott, Silverman, and Bowman 2016, 12)? The acknowledgement that citizenship carries both privileges and obligations begs the question: how might we describe and demonstrate those values of artistic citizenship deemed important for education without invoking the inherent normativity and exclusion within the terminology of citizen and citizenship?

Bradley, Deborah. 2018. Artistic citizenship: Escaping the violence of the normative(?) Action, Criticism, and Theory for Music Education 17 (2): 71-91. doi:10.22176/act17.2.71 
In looking at the combination of artistic activism and citizenship, I am drawn to questions directly related to the public good. As Bowman (2002) has written, most music educators believe that "experiencing and making art changes who we are and what we expect from life" (63). Activists often rely on the belief that their art conveys social messages that may fly under the radar of scrutiny from politicians and others portrayed negatively. But we need to unpack these notions when combined into the concept artistic citizenship. Elliott, Silverman, and Bowman (2016) state:

the opposition between artistry and citizenship is apparent only if connected to the unfortunate semantic baggage of the 18th century notions about artistry ... aesthetic, "fine art," or "work-centered" concepts of artistry, in which "true" art and "true artists" supposedly disavow practical, civic, or political purposes. (Elliott, Silverman, and Bowman 2016, 7, emphasis added)

While undoubtedly such 18th century semantic baggage complicates the concept of artistic citizenship, the baggage to which these authors point seems confined to notions of artistry and aesthetics. What about the baggage the term citizenship carries?

Liberal scholars have an affinity for critique, and I do not seek to distance myself from such affinity in my endeavor here. After all, "critique is fun.... There is a joy and a pleasure in righteous critique” (Brandzel 2016, Kindle loc. 36). However, it is important to understand that citizenship itself represents a discourse of inclusion, and that "aspirations for inclusion [may] recreate violence against vulnerable peoples" (Kindle loc. 51). Brandzel asks, "How does the righteous indignation of radical critique refuse to witness the pain of normative exclusion?" (Kindle loc. 64). In similar vein, I ponder whether the very concept of artistic citizenship represents a discourse of privilege that recreates violence against vulnerable peoples, or fails to witness their pain, despite attempts to "privilege their voices" (Hess in press). Even when used metaphorically, the term citizenship cannot divorce itself completely from the legal definition.

What might artistic citizenship as concept mean for those vulnerable to machinations of the state: persons without citizenship status, such as immigrants to a new homeland, or refugees who have fled dangerous conditions only to meet rejection at the doors on which they knock? What might artistic citizenship mean under a repressive government, where visibility as an artist-activist must be

Bradley, Deborah. 2018. Artistic citizenship: Escaping the violence of the normative(?) Action, Criticism, and Theory for Music Education 17 (2): 71-91. doi:10.22176/act17.2.71 
avoided, as Niknafs explores in the work of the underground or "unofficial musicians" in Iran (Niknafs 2016, 2017)? What might artistic citizenship mean for athletes in the United States whose peaceful protests against racial injustice resulted not only in criticism from the U.S president himself but in at least one case has led to loss of employment? ${ }^{1}$ In this paper, I probe these and other questions related to concepts of artistry, activism, and citizenship.

\section{Normativity and Exclusion: Concepts of Citizenship}

As Wayne Bowman (2016) asserts, "The questions of whom citizenship includes, whom it excludes, why, and how are therefore critical to a full appreciation of its potential sociopolitical ramifications" (62). If indeed we want to think about artistic citizenship's relation to the citizenship component of the term, the questions of inclusion and exclusion become primary. While it is beyond the scope of this paper to provide a thorough historical background into the various meanings of citizenship across millenia and cultures, I believe it is worthwhile to look at how the residue of meanings from the historical past remain influential to today's thinking about citizenship. Although the term at one point may have had a "unitary, stable meaning, citizenship is now diffuse, multiple, and ever-shifting. Originally defined clearly by geographical borders and a common history, citizenship is increasingly in question" (Hébert and Wilkinson 2002, 3).

The early Greek city-states usually receive credit for the first applicable concepts of citizenship. Citizenship was originally determined by birthright within the Greek city-states. The status was reserved solely for men but required some degree of participation in the governing of the polis (which referred to both the political assembly and the society generally) and within which the rule of law prevailed. Over time, notions of consent versus descent took hold, leading eventually to the allowance for citizenship by choice (Hébert and Wilkinson 2002). In ancient Athens, citizenship extended only to male property owners and to their male progeniture, and excluded women, children, the poor, and slaves (5). The Romans believed citizenship "to be a legal status with cosmopolitan character. It was widely distributed throughout the empire, holding an assimilative strength in order to create loyalty among a rapidly growing population of great diversity" (Hébert and Wilkinson 2002, 5). While the requirement to hold property has been dropped 
from Western concepts of citizenship, the cosmopolitan characteristics of assimilating diverse populations remains, and may also be seen in the increasing numbers of people holding multiple passports as an enactment of individual cosmopolitanism (Ong 1999, Brennan 1997).

In a vein similar to Bowman's query, Anthony Downey (2014) asks readers to consider the question, "what is a citizen?" (64). As he writes, at its most basic level, a citizen is someone entitled to legal protection by the state by right of birth or through a process of naturalization, and in return for that protection, pledges loyalty to the state. This concern for loyalty to the state has its own long history-Plato advised that "citizens be taught myth to enhance their state loyalty" (Martin 2006, 11, italics added). What weight may be applied to either the concepts of protection or loyalty has recently become the topic of much debate and politicization, which I discuss in the next paragraph; however, as Downey (2014) asserts: "What remains clear is that the citizen is legally protected, whereas the non-citizen remains grievously unprotected and susceptible to harm, injustice, and deprivation" (64). What is also clear is that this definition of citizen, with its legal, social, philosophical, and governmental underpinnings, excludes a great many people: non-citizens, refugees, the dispossessed, the disappeared, the incarcerated, migrants, immigrantseven those with "permanent resident" status. The numbers of non-citizens around the world continue to increase dramatically as bombs explode, glaciers melt, waters and temperatures rise on planet Earth, forcing ever more people out of their homes and their locations of birthright citizenship.

The guarantee of protection from the state implied by citizenship, unfortunately, is tenuous at best. Over the past century, citizenship became inextricably entwined in concepts of nationalism and nation-states that have evolved into "the strident forms of nationalism that have taken the aftermath of September 11, 2001, as justifying a legally enforceable patriotism" (Martin 2006, 10). The very concept of protection as a benefit of citizenship now appears to be in jeopardy from laws proposed to prohibit freedom of speech and the right to peaceful protest (Baniewicz 2018). Such laws seek to reinforce a docile public, what Power (2012) describes as "the acceptable public, the one invoked by the state in the name of the preservation of order ... the mute, static public used against the mobile, protesting public" (cited in Vujanovic 2016, 105).

Nationalism's "dark side" places the state in the paradoxical position of being both the guardian of human rights and the instrument for the abuses of those

Bradley, Deborah. 2018. Artistic citizenship: Escaping the violence of the normative(?) Action, Criticism, and Theory for Music Education 17 (2): 71-91. doi:10.22176/act17.2.71 
rights (Hébert and Wilkinson 2002, 6). As has been demonstrated by feminists and antiracists, the concept of citizenship has been used to "police the boundaries of who might participate in society, excluding immigrants, people living in poverty, women, and so forth" (Skillshare 2016, 215). The United States and Canada each have a long history of mistreating both citizens and non-citizens who represent "the other": Native Americans, First Nations, Métis, and Inuit, Black Americans and Canadians, Muslims, those who identify as lesbian, gay, bisexual, transgender, queer or questioning, or two-spirited-the list is long indeed.

For example, in Canada under Prime Minister Steven Harper, the Conservative government passed bill C-24, the Citizenship Act. One of the provisions of this legislation made it possible for the federal government to revoke the Canadian citizenship of anyone who also held citizenship in another country if convicted of "treason, spying, or terrorism offences." The revocation of citizenship could occur without formal charges, a trial, or any form of due legal process. The language of the bill was sufficiently vague as to allow for broader application. This bill was "corrected" by the current Liberal majority government's Bill C-6, an Act to amend the Citizenship Act, ${ }^{2}$ which reinstated the right to a trial to determine whether citizenship should be revoked or not, and removed the bill's discriminatory language, largely as the result of continued pushback and activism from the citizenry. Bill C6 became law in June 2017; however, the point remains that citizenship in the legal sense offers little to no real security. It may be granted and revoked at any time, and an individual so affected may have no legal recourse to the revocation of citizenship. Citizens offer their loyalty but may receive little of the promised security. Despite corrections that may "improve" previous legislation, laws continue to be written that exclude some people from the benefits of citizenship, exemplified by recent Executive Orders from the U.S. president banning travel from six Muslimmajority countries, 3 thus prohibiting people in search of a place of safety from gaining legal access to the U.S., where the possibility of eventual citizenship, with its supposed freedoms and benefits, sings a siren song. 4

As Brandzel (2016) argues, the siren song of citizenship as a discourse of inclusion has widespread and magnetic appeal. Citizens who do not currently receive equal treatment under the law also long to be included among those who receive its presumed full protection; those who do not yet have the benefit of citizenship seek to be enfolded into the category of citizen, often without much consideration

Bradley, Deborah. 2018. Artistic citizenship: Escaping the violence of the normative(?) Action, Criticism, and Theory for Music Education 17 (2): 71-91. doi:10.22176/act17.2.71 
to the possible price to be paid. Admission to "the club" of citizenship invokes a process of normative inclusion that

entrenches notions of proper versus improper, natural versus abnormal, and normative versus abject. There is no such thing as a movement for inclusion and citizenship for some that does not further the vulnerability and disenfranchisement of others. (Brandzel 2016, Kindle loc. 53)

Raising this critique of artistic citizenship may well cause discomfort for some people. After all, citizenship is not inherently a "bad thing"; millions around the world covet the opportunity to become citizens of the United States, Canada, Great Britain, Australia, Germany, France, or other nations. As Aiwa Ong (1999) illustrated, citizenship may be so desirable that some people seek and obtain multiple passports as a way to maximize their rights and responsibilities globally. And to speak of citizenship metaphorically, as Elliott, Silverman, and Bowman (2016) use the term, invokes what many readers will no doubt consider to be desirable values: a sense of social responsibility that leads artists to use their position to challenge injustice through artistic endeavors. The critique of citizenship in itself represents a paradox, which Brandzel identifies in her question, "What does it mean to speak about victims and perpetrators of normative violence in such a way as to be accountable, or at the very least, present for the pain that this can cause" (Brandzel 2016, Kindle loc. 63-4)? In other words, raising the questions themselves may cause pain for those on all sides of the citizenship debate.

The legal definition of citizenship forms a key point in my exploration of artistic citizenship's metaphorical meaning, particularly as it relates to those educators who seek to cultivate a sense of social responsibility-of "good citizenship"-among their students. What might teacher talk about being a good citizen mean to undocumented students who fear they may be deported following from the U.S. president's attempts to repeal DACA; 5 what might talk about being a good citizen mean to refugees, to immigrants from countries ruled by authoritarian governments, or to Muslim students whose physical presence invokes both spoken and unspoken racist fears about terror among their classmates or teachers? It seems to me that the language of good citizen may sound subtly threatening to a great many students. When the U.S. president howls from the bully pulpit that professional football players who exercise their right to free speech by kneeling during the national anthem should "be fired," 6 the very notion of what constitutes good citizenship related to social responsibility becomes at risk. With such statements influencing

Bradley, Deborah. 2018. Artistic citizenship: Escaping the violence of the normative(?) Action, Criticism, and Theory for Music Education 17 (2): 71-91. doi:10.22176/act17.2.71 
most arenas of public discourse in the U.S., how likely is it that students traumatized by fear of deportation hear the term citizen and think metaphorically about its meaning? My interest here aligns with Brandzel's-to "create scholarship that is not only critical, but accountable to those actors and agencies whose political actions we so often find lacking, assimilationist, ethically bankrupt, or, even more painfully, culpable for re-creating violence against nonnormative peoples" (Brandzel 2016, Kindle loc. 90).

\section{Social Responsibility and the Role of the Arts and Artists}

If the goal of education for artistic citizenship is presumed to be that of developing socially responsible behavior, 7 we need to have some understanding of what sort of behavior constitutes "social responsibility." Social responsibility is usually defined in reference to both local and global issues of social justice, voiced as concerns for: unjust distribution of goods and services to the vast majority of the global population; the oppression of women and those dependent upon them; the repression of large populations based on race, ethnicity, language, or religion; the unjust exploitation of nature by processes that result in damage or destruction to the environment and human ecology; and the ever growing injustice of militarism and continuous warfare (Dyck 2014). Such issues cannot be addressed easily in any setting, and within school settings particularly in North America, current concerns for standardized tests and test scores (and thus topics easily distilled into multiple choice responses) may represent topics that some teachers fear to even undertake. At best, the time consumed by testing minimizes the amount of time that topics related to social responsibility receive, and when they are addressed, it is often as "special class projects" or individual research projects. For those brave enough to tackle such gravely important issues, however, the arts can provide a rich and nuanced means through which to encourage and support student engagement.

Without question, artists (and when I use the term artists I include musicians, dancers, visual artists, filmmakers, novelists, poets-anyone involved in the creation of art of any kind) have a long history of using their artistic activity to make social, political, and even "purely artistic" statements that may, intentionally, or not, promote engagement with social and political issues. Whether any artistic endeavor can be truly devoid of the social and political climate comprising the habitus (Bourdieu 1977) in which that art was created has been discussed at length over

Bradley, Deborah. 2018. Artistic citizenship: Escaping the violence of the normative(?) Action, Criticism, and Theory for Music Education 17 (2): 71-91. doi:10.22176/act17.2.71 
the years, and is not central to my concerns in this article. Yet as Diverlus (2016) states, "not all art must include an explicit political message ... there is always room for abstractions, as well as miscellaneous, personal, form- and curiosity-driven art" (192). Curiously, though, nearly all the examples of artistic citizenship provided in the various books I consulted, including Elliott, Silverman, and Bowman (2016), contain political or socially critical messages, and thus my concern relates to art that intentionally makes such statements-the "bad" citizens about whom Vujanovic (2016) writes, who exercise their artistry as a way of addressing the public good. Thus I ask, does the role of educators imply an obligation to help students learn to be "bad citizens"-to make their own artistic political or social statements?

\section{Activism/Artivism}

Diverlus (2016) asks, "Is artivism a core function of artistry or an addendum?" (190). It seems that most authors utilizing the term artistic citizenship approach their discussions from the perspective of core function. Diverlus himself appears to assume that art and activism are inextricably connected, despite his admission that not all art must contain a social message, and his further acknowledgement that activist art sometimes fails to achieve its educational potential. He describes artivists who might do the important work of troubling the hegemonic "mainstream," but who fail in their educational goals to build capacity or create stronger networks of emerging artivists (191). His questions related to the role of the arts in education resonate with my own concerns about education as-for antiracism and social justice more broadly:

- What are the responsibilities, if any, of arts educators ... to focus on form and the social roles of the arts and artists?

- What are the responsibilities of artists in visioning, imagining, and organizing for a more just society?

- Do artists bear a responsibility to make their craft, their audiences, and their communities more socially engaged? (Diverlus 2016, 190)

In considering such questions, however, we must keep in mind that efforts in artivism may hold as much potential for ill as for good. For example, Wiles (2016) describes how the opera, Der Jasager ("He Who Says Yes"), on which Bertolt Brecht and Kurt Weill collaborated in 1930, was originally intended to convey a socialist ideal of good citizenship in response to the political crisis resulting from icism, and Theory for Music Education 17 (2): 71-91. doi:10.22176/act17.2.71 
the rise of fascism. The libretto's story, modeled on a feudal Japanese morality play, expressed "the need of the individual to suppress his or her immediate human impulses for the sake of a long-term collective good" (30). Brecht and Weill promoted the opera as part of a series of short "learning plays," to be performed by school children throughout Germany. Unfortunately, the feudal value espoused in a tale about the sacrifice of self for benefit of the majority was quickly interpreted as supporting Nazi ideology. "The piece that had aspired to be a lesson in citizenship became all too easily a lesson in National Socialism" (32).

I offer Wiles' (2016) cautionary tale of Der Jasager to remind educators that our pedagogical practice, even practice in support of "good citizenship" (including antiracism and social justice forms of education) cannot guarantee what meaning learners may take away (Simon 1992, 61). Even so, educators with a strong sense of social justice no doubt recognize and enact what Diverlus (2016) calls a responsibility to envision, imagine, and organize teaching to promote a more just society (190). As he argues, artivism may represent an important form of response to the current neoliberal realities of life in the world today: where the global attack on women's reproductive rights bears relationship to the infringement of indigenous treaty rights and to the exacerbated rates of homelessness and forced global migration. "From a global perspective, social justice issues are very much linked, and they influence and feed each other as a result of everything else being globalized: economies, political systems, entertainment, and so forth" (Diverlus 2016, 191).

Yet Diverlus' perspectives on social justice and artivism are not universally accepted among artists who also consider themselves activists. For example, in the 2014 book, Art and Politics Now, Anthony Downey (2014) came to the realization that many of the visual artists whose work he highlighted rejected the label of political activist-not out of fear of being so labeled, nor from concerns for aesthetic purity, but because they viewed the label as "yet another way of limiting the potential of their practice to offer different ways of engaging with and reimagining the boundaries of the political sphere" (21, italics added). In similar vein, I wonder if the term artistic citizenship represents a potential limitation on practice, or perhaps more to the point: does an educational focus on the development of artistic citizens-or on artistic citizenship-as-metaphor-put at risk some of the very students whom we hope to benefit? Students whose experiences of social injustice, of life in a refugee camp, of arduous journeys to a new homeland, undoubtedly can derive benefit from being able to translate their experiences into powerful stories,

Bradley, Deborah. 2018. Artistic citizenship: Escaping the violence of the normative(?) Action, Criticism, and Theory for Music Education 17 (2): 71-91. doi:10.22176/act17.2.71 
poems, songs, or dances. Yet in our efforts to develop artistic citizens in the classroom, do we do violence to students whose first desire may be simply to be included in the (legal) category of citizen? Do we place those students at risk for further injustice when their aspirations for full inclusion come at the (impossible) price of assimilation into normative society (Bedard 2000, 51, Bradley 2009)?

\section{Artistic Citizenship as a Discourse of Exclusion and Normativity}

From one viewpoint, it seems almost too easy to critique the concept of artistic citizenship as an exclusionary, normative concept. After all, anything that speaks to the type of imagined community (Anderson 1983) that the term citizenship invokes, of necessity also invokes those on the margins of that community-the "nation of noses pressed up against the glass" (Henley, Lynch, and Corey 1989), as Don Henley's lyrics so eloquently expressed. But to dismiss as wannabees those who desire to be fully included fails to recognize the real struggles of life on the margins. Inclusion comes at a cost.

In exploring the legalization of same-sex marriage, Brandzel (2016) writes: "This desire for inclusion denotes not only the disavowal of racialized structures of power, but also represents a direct retreat from queer politics that opposed statebased legitimacy and recognition" (Brandzel 2016, Kindle loc. 110-11). According to Brandzel, the retreat from queer politics suggests being "seduced by empire" (120), a biopolitical process through which the emergence and sanctioning of queer subjecthood represents a historical shift condoned through a process of demarcation from [other] populations that have been targeted for segregation, disposal, or death (120-22). In other words, the journey to normativity and inclusion often results in the abjection of others.

Gould (2016) makes a similar argument related to gay, lesbian, queer, bisexual, and transgender studies as a discourse that is "normalizing" within music education:

Based on the assumption that normativity leads to tolerance, if not acceptance, the push to normalize (selected) variant sexualities, typically as a function of whiteness, is ubiquitous, notwithstanding music education's tardiness. To the extent that it occurs in correspondence with preestablished norms, however, normativity is achieved through assimilation. (Gould 2016, 123)

As many have written, assimilation serves as an erasure of identity, yet for particular populations, assimilation is simply unachievable (Bedard 2000, Bonilla-Silva

Bradley, Deborah. 2018. Artistic citizenship: Escaping the violence of the normative(?) Action, Criticism, and Theory for Music Education 17 (2): 71-91. doi:10.22176/act17.2.71 
2003). Thus, if artistic citizenship relies upon concepts of citizenship as a normalizing discourse, it joins the list of inclusion discourses that often fail in their goals to include.

I think here of my long-standing love-hate with the Canadian national anthem's lyrics. I am a natural-born citizen of the United States but have spent most of my adult life in Canada as a citizen of that adopted homeland. For many years, however, I have struggled to sing the lyrics: "our home and native land" and "true patriot love in all thy sons command." I am neither a native of Canada nor anyone's son. ${ }^{8}$ When I applied for Canadian citizenship, I very much desired the benefits and privileges it offered. Even so, by seeking and accepting that citizenship, I became complicit with the whiteness, patriarchy, and colonialism on which the nation was founded and continues to operate, symbolically conveyed by the anthem's opening lines, which I typically sing as "our home ON native land." Perhaps my academic work in anti-oppression education represents penance for the bargain I struck in order to acquire a Canadian passport. As a White woman and citizen of both the U.S. and Canada, two countries with long and horrendous histories of abuse, my complicity in exclusionary citizenship suggests I have something for which to make amends.

At the same time, however, we must consider the complex ways that desiring normativity might represent, or might even primarily be, a strategy of survival. While those "seduced by empire" may be criticized for their participation in whitenormative, heteronormative citizenship, we cannot ignore, indeed we must remain present to, "the types of violence and trauma that create the conditions for and precede the "normative strivings.' The fantasies and seductions ... are motivated in part by pain, and a desire to end the suffering and violence of exclusion" (Brandzel 2016, Kindle loc. 137-40). W.E.B. DuBois wrote of this pain, this longing to end the violence of exclusion:

...this longing ... to merge his double self into a better and truer self. In this merging he wishes neither of the older selves to be lost. He would not Africanize America, for America has too much to teach the world and Africa. He would not bleach his Negro soul in a flood of white Americanism, for he knows that Negro blood has a message for the world. He simply wishes to make it possible for a man to be both a Negro and an American. (Du Bois 1903/2003, 9)

To denigrate the desire for full citizenship represents yet another act of violence against those whose very desires may represent personal survival strategies, and the very human desire for acceptance.

Bradley, Deborah. 2018. Artistic citizenship: Escaping the violence of the normative(?) Action, Criticism, and Theory for Music Education 17 (2): 71-91. doi:10.22176/act17.2.71 


\section{Artistic Citizenship: Discourse of Privilege?}

Early in this paper, I raised the question of whether artistic citizenship might be representative of a discourse of privilege. After all, to even be able to critique the concept implies a freedom of speech and an assumed right to express alternative opinions. Yet artists do exist who express social responsibility through their works, often at their own peril. Their works speak in lieu of words that they may be otherwise prohibited from uttering publicly. The bravery of these artists, musicians, dancers, poets, novelists, etc. must be acknowledged and respected; they act while some of us talk about what their actions mean.

The discussion about whether or not artistic citizenship represents a discourse of privilege that potentially does harm to marginalized communities and individuals ignores the fact that the discourse of privilege is itself a discourse of privilege. Herein lies the problem, rather than in the discourse of artistic citizenship. When the discourse of privilege critiques the role of activists in any field, it serves to censure and to support hegemony, leading

activists to a political dead end, because if taking to the streets is too radical and harmful to oppressed communities, then they are left mired in white guilt, signing futile petitions and calling their Congressmen. When revolution becomes denigrated as "privileged," maintenance of the status quo becomes the order of the day. (Kovac 2017, 5)

This is not to say that discussion about discourses of privilege should be avoided altogether. Such discussions become instrumental for our understanding of how dominant groups accrue social benefits at the expense of the dominated; however,

under the guise of elevating the concerns of all oppressed people, it in fact argues for the advancement of domestic policy priorities for some segments of the U.S. population while relegating other racial and religious communities to the margins of the margins. (Kovac 2017, 3-4)

As Kovac (2017) explains, the problem arises when charges of privilege are "deployed opportunistically against third-party voters, non-voters, anti-fascists and anyone else deemed to have paid insufficient fealty to the current party of liberal pragmatism" (5).

While my discussion in this article is on arts activism, or artivism as some prefer, and taking to the streets in protest represents a different form of activism than that of artistic output, I take Kovac's admonitions about discourses of privilege seriously. Kovac's point may be extended to include academic writing as representing

Bradley, Deborah. 2018. Artistic citizenship: Escaping the violence of the normative(?) Action, Criticism, and Theory for Music Education 17 (2): 71-91. doi:10.22176/act17.2.71 
privilege, in large part due to the presumed insularity of the academic audience (Rothman 2018). Yet at the same time, academic work may be as much a form of artistic citizenship as any other art form. Academics in disciplines such as history, English, political science, philosophy-yes, even music education philosophy-often first think of themselves as writers whose interests lie in issues both practical and spiritual. Typically, we intend for our writing to be read by a small but engaged audience, and thus we take great care with the words we choose, often searching for hours for the right quotation or the best argument to support our points, synthesizing what we read much the way an artist blends paint to produce the perfect color or shade. Academic writing is crafted to meet a somewhat ambiguous set of expectations required by its readers:

It's supposed to be dry but also clever; faceless but also persuasive; clear but also completist. Its deepest ambiguity has to do with audience... But, because it's intended for a very small audience of hyper-knowledgable, mutually acquainted specialists, it's actually among the most personal writing there is. (Rothman 2018, 1-2)

In the interests of a philosophy open to various strategies for dealing with the concept of artistic privilege, I think we may do a disservice to the scholars and the scholarship devoted to the concept of artistic citizenship, and an even bigger disservice to those who practice artistic citizenship or social responsibility through their work, by dismissing the concept outright as a discourse of privilege. Of course, if discussions about artistic citizenship never venture beyond the ivy-covered walls, then perhaps accusations of a discourse of privilege have some merit.

\section{Contingent Solidarity: Dreaming Impossible Dreams}

I hope by this point in the paper that it is clear that I am not averse to the work of artistic citizenship; my main concern is in the language of artistic citizenship itself, which is inextricably linked to concepts of nation, statehood, and exclusion. For example, in a chapter entitled "Poet as Citizen in a Contested Nation: Rewriting the Poetry of Soviet-Occupied Afghanistan," Aria Fani (2016) attempts to unhinge the concept of artistic citizenship from any presumed loyalty to the nation:

The notion of artistic citizenship allows us to consider different poetics that engage what it means to be loyal to a nation at a critical juncture in which artists ... attempt to understand an event of global magnitude in all its complexities across a large spectrum of politics and poetics. (394)

Bradley, Deborah. 2018. Artistic citizenship: Escaping the violence of the normative(?) Action, Criticism, and Theory for Music Education 17 (2): 71-91. doi:10.22176/act17.2.71 
In this statement, Fani invokes both a metaphorical and legal meaning for citizenship, offering inclusion to all artists who use their work to understand significant events. Even so, he upholds the citizenship bargain in his reference to loyalty to the nation, leading us back to the questions that prompted my initial concerns: Do non-citizens have the same freedom to create critical artworks as citizens? Do some people and populations risk more in expressing social responsibility than others, even those who may be citizens through birthright or oath of allegiance? How does citizenship's implication of belonging to the nation complicate efforts to teach for social responsibility, as, for example, in Brecht's attempt to create art that demonstrated socialist ideals of good citizenship (Wiles 2016)?

It is easy to think of notable personalities who have expressed themselves artistically, as "bad citizens for the public good" (Vujanovic 2016) and who have paid a price for their efforts. For example, Natalie Mayne of the Dixie Chicks received death threats after an off-the-cuff jocular but unflattering remark about then Pres. George W. Bush during a concert in London, UK, and the fan backlash nearly ended the group's performing career. British actress Vanessa Redgrave's contract with the Boston Symphony Orchestra was terminated, allegedly as a result of remarks she made supporting the Palestinian cause in the Arab-Israeli conflict (Fell 2010, 3). Another example comes from renowned contemporary artist Ai Weiwei, who has been beaten and imprisoned several times for his artistic critiques of his native China, where he continues to live and to hold citizenship.

What do we mean when as educators we talk about developing artistic citizenship among our students? In Canada, the U.S. and throughout Europe, one can be fairly certain that not all the students in any classroom identify as citizens. If we invoke the term in our teacher talk, do we potentially harm those students who are vulnerable to the machinations of the state, or perhaps set them up for unrealistic expectations of security in return for loyalty should they eventually acquire citizenship in the legal sense?

I firmly believe that our role as music educators is to encourage students to develop social responsibility: to care for one another, to care for the environment, to reject racism and heterosexism, and to help them find ways to express that social responsibility artistically. This at times seems to be the teacher's impossible dream-for students to become artistically and socially responsible; the reality of teaching means that we often never know the outcome of our efforts, because "learning occurs in belated time" (Britzman 1998, 26). This impossible dream of

Bradley, Deborah. 2018. Artistic citizenship: Escaping the violence of the normative(?) Action, Criticism, and Theory for Music Education 17 (2): 71-91. doi:10.22176/act17.2.71 
teaching represents a tall order-an ethical and moral obligation that we must accept if we call ourselves educators. However, the performativity of the arts provides us with the means for encouraging social responsibility without specifically calling it artistic citizenship. As Britzman (1998) also warns us, we deal with difficult knowledge that has the potential to traumatize or to recreate experiences of trauma. The quest for difficult knowledge thus invokes its own bargain:

Studying the experiences and the traumatic residuals of genocide, ethnic hatred, aggression, and forms of state-sanctioned-and hence legal-social violence requires educators to think carefully about their own theories of learning and how the stuff of such difficult knowledge becomes pedagogical. (Britzman 1998, 117)

How do we make such difficult knowledge pedagogical? As educators, we can model social responsibility for our students in the music we teach and program for concerts, the artworks and poetry we select for lessons, the music theatre we bring into our classrooms, and the discussions in which we engage in our pedagogy. Providing deep context for the songs, the art, the drama, the poems, and the novels

gives students a starting point to witness and understand how social responsibility and the arts intertwine, made visible through important examples of protest art, music, poetry, and literature. But educators need to practice artivism responsibly, with care and intent, in order to avoid the potentially negative implications concepts such as artistic citizenship might invoke. The words we choose to use in the classroom become their own poetics. May the songs we sing carry messages of social responsibility-songs that avoid the rhetorical trap terms such as artistic citizenship-even when used metaphorically, cannot fully escape.

\section{About the Author}

Deborah Bradley received a Ph.D. in Sociology and Equity Studies in Education from OISE/University of Toronto. She was Assistant Professor in the Department of Curriculum and Instruction at the University of Wisconsin-Madison from 2006- 2010, and taught at the University of Toronto from 1997-2005 and 20102014. She retired from UW-Madison in 2010 and the University of Toronto in 2014. Her publications on antiracism education include articles in ACT, Philosophy of Music Education Review, Journal of Aesthetic Education, Music Education Research, Theory into Practice, and chapters in several Oxford University Press handbooks: Philosophy of Music Education (2012), Handbook of Music Education and Social Justice (2015), the Handbook of Choral Pedagogy (2016), and College

Bradley, Deborah. 2018. Artistic citizenship: Escaping the violence of the normative(?) Action, Criticism, and Theory for Music Education 17 (2): 71-91. doi:10.22176/act17.2.71 
Music Curricula for a New Century (2017). Deb has served as Editor in Chief for MayDay Group publications since 2015.

\section{References}

Anderson, Benedict R. 1983. Imagined communities: Reflections on the origin and spread of nationalism. London: Verso.

Baniewicz, Christine. 2018. Under Louisiana bill, peaceful protesters could face 20 years in prison. [Article], Last Modified Apr 18.

Bedard, Gabriel. 2000. Deconstructing Whiteness: Pedagogical implications for anti-racism education. In Power, knowledge, and anti-racism education: A critical reader, edited by George Sefa Dei and Agnes Calliste, 41-56. Halifax, Nova Scotia: Fernwood Publishing.

Bonilla-Silva, Eduardo. 2003. Racism without racists: Color-blind racism and the persistence of racial inequality in the United States. Lanham: Rowman \& Littlefield.

Bourdieu, Pierre. 1977. Outline of a theory of practice, Cambridge studies in social and cultural anthropology; 16. Cambridge; New York: Cambridge University Press.

Bowman, Wayne. 2002. Educating musically. In The new handbook of research on music teaching and learning, edited by Richard Colwell and Carol Richardson, 63-84. New York: Oxford University Press.

Bowman, Wayne D. 2016. Artistry, ethics, and citizenship. In Artistic citizenship: Artistry, social responsibility, and ethical practice, edited by David J. Elliott, Marissa Silverman and Wayne D. Bowman, 59-80. New York: Oxford University Press.

Bradley, Deborah. 2009. Oh that magic feeling! Multicultural human subjectivity, community, and fascism's footprints. Philosophy of Music Education Review $17(1): 56-74$.

Brandzel, Amy L. 2016. Against citizenship: The violence of the normative, Dissident feminisms. Urbana, Illinois: University of Illinois Press.

Brennan, Timothy. 1997. At home in the world: Cosmopolitanism now. Cambridge, Mass.: Harvard University Press.

Bradley, Deborah. 2018. Artistic citizenship: Escaping the violence of the normative(?) Action, Criticism, and Theory for Music Education 17 (2): 71-91. doi:10.22176/act17.2.71 
Britzman, Deborah P. 1998. Lost subjects, contested objects: Toward a psychoanalytic inquiry of learning. Albany, NY: State University of New York Press.

Campbell, Mary Schmidt, and Randy Martin. 2006. Artistic citizenship: A public voice for the arts. New York: Routledge.

Diverlus, Rodney. 2016. Re/imagining artivism. In Artistic citizenship: Artistry, social responsibility, and ethical praxis edited by David J. Elliott, Marissa Silverman, and Wayne Bowman, 189-210. New York: Oxford University Press.

Downey, Anthony. 2014. Art and politics now. London: Thames and Hudson.

Du Bois, W. E. B. 1903/2003. The souls of black folk. New York: Barnes \& Noble, Inc.

Dyck, Robert. 2014. Youth education for social responsibility. Systems Research and Behavioral Science 32 (2): 168-74. doi: 10.1002/sres.2256.

Elliott, David J., Marissa Silverman, and Wayne Bowman, eds. 2016. Artistic citizenship: Artistry, social responsibility, and ethical praxis. Kindle edition. New York: Oxford University Press.

Fani, Aria. 2016. Poet as citizen in a contested nation: Rewriting the poetry of Soviet-occupied Afghanistan. In Artistic citizenship: Artistry, social responsibility, and ethical praxis, edited by W. Bowman, D. J. Elliott and Marissa Silverman, 392-414. New York: Oxford University Press.

Fell, Alan. 2010. Unlikely muse: Legal thinking and artistic imagination. New York Law Journal 244 (18): 1-4.

Gould, Elizabeth. 2016. Ecstatic abundance: Queer temporalities in LGBTQ studies and music education. Bulletin of the Council for Research in Music Education 207-208: 123-17. doi: 10.5406/bulcouresmusedu.207-208.0123.

Hébert, Yvonne M., and Lori Wilkinson. 2002. The citizenship debates: Conceptual, policy, experiential, and educational issues. In Citizenship in transformation in Canada, edited by Yvonne M. Hébert, 3-36. Toronto: University of Toronto Press.

Henley, Don, Stanley Lynch, and John Corey. 1989. Gimme what you got (Recorded by Don Henley). In End of the innocence. New York: UMG Recordings.

Bradley, Deborah. 2018. Artistic citizenship: Escaping the violence of the normative(?) Action, Criticism, and Theory for Music Education 17 (2): 71-91. doi:10.22176/act17.2.71 
Hess, Juliet. 2018. Singing our own song: Navigating identity politics through activism in music. Research Studies in Music Education [preprint]. doi: 10.1177/1321103X18773094

Kornstein, Daniel J. 2010. Unlikely muse: Legal thinking and artistic imagination. Bloomington, IN: Authorhouse.

Kovac, Matthew. 2017. How mainstream privilege discourse actually bolsters the status quo. [Article], Last Modified Jun 04. http://www.truthout.org/news/item/40798-how-mainstream-privilege-discourse-actuallybolsters-the-status-quo.

Martin, Randy. 2006. Artistic citizenship: Introduction. In Artistic citizenship: A public voice for the arts, edited by Mary Schmidt Campbell and Randy Martin, 1-22. New York: Routledge.

Niknafs, Nasim. 2016. In a box: a narrative of a/n (under)grounded Iranian musician. Music Education Research 18 (4): 351-63. doi:10.1080/14613808. 2016.1202222.

Niknafs, Nasim. 2017. "Khas-o-Khâshâk": Anarcho-Improv in the Tehrani music education scene. In Punk pedagogies: Music, culture and learning, edited by Gareth Dylan Smith, Mike Dines, and Tom Parkinson, 30-42. New York: Routledge.

Ong, Aihwa. 1999. Flexible citizenship: The cultural logics of transnationality. Durham, NC: Duke University Press.

Power, Nina. 2012. Good public is a moving public. TkH (Teorija koja hoda/Walking Theory: Journal for Performing Arts Theory) 20: 10-15.

Rothman, Joshua. 2018. Why is academic writing so academic? The New Yorker, Feb 20, 1-5.

Shear, Michael D. 2017. New order indefinitely bars almost all travel from seven countries. New York Times, September 24, 2017, Politics. https://www. nytimes.com/2017/09/24/us/politics/new-order-bars-almost-all-travelfrom-seven-countries.html?mcubz=0\&_r $=0$.

Simon, Roger I. 1992. Teaching against the grain: Texts for a pedagogy of possibility. Toronto: Ontario Institute for Studies in Education.

Skillshare, Ste-Émilie. 2016. Queer and trans people of color community arts collective. In Artistic citizenship: Artistry, social responsibility, and ethical praxis, edited by David J. Elliott, Marissa Silverman, and Wayne Bowman, 213-32. New York: Oxford University Press.

Bradley, Deborah. 2018. Artistic citizenship: Escaping the violence of the normative(?) Action, Criticism, and Theory for Music Education 17 (2): 71-91. doi:10.22176/act17.2.71 
Tasker, John Paul. 2018. Senate passes bill to make O Canada lyrics gender neutral. CBC News, Last Modified Jan 31, accessed 5/2/2018. http://www.cbc.ca/news/politics/anthem-bill-passes-senate-1.4513317.

Vujanovic, Ana. 2016. Art as a bad public good. In Artistic citizenship: Artistry, social responsibility, and ethical praxis, edited by David J. Elliott, Marissa Silverman, and Wayne Bowman, 104-122). New York: Oxford University Press.

Wiles, David. 2016. Art and citizenship: The history of a divorce. In Artistic citizenship: Artistry, social responsibility, and ethical praxis, edited by David J. Elliott, Marissa Silverman, and Wayne Bowman, 22-40. New York: Oxford University Press.

Willen, Liz. 2013. Ball of confusion: How 'edu-speak' leaves too many parents behind-The Hechinger Report. [Commentary], Last Modified Sep 17

\section{Notes}

${ }^{1}$ Colin Kaepernick of the NFL San Francisco 49'ers chose to kneel for the U.S. national anthem in August 2016 to protest the treatment of minorities in the U.S. Since his contract with San Francisco has expired, no other team has hired him, despite the now wide-spread similar protests by NFL players and owners.

${ }^{2}$ For details see https://www.canada.ca/en/immigration-refugees-citizenship/news/2017/o6/bill_c-6_receivesroyalassento.html

3 The most recent ban, dated September 24, 2017, indefinitely prohibits travel for persons from Iran, Libya, Syria, Yemen, Somalia, Chad, North Korea, and Venezuela. Legal scholars have suggested that the inclusion of North Korea and Venezuela on the list serves to discredit claims that the order represents anti-Muslim sentiment (Shear 2017). The ban took effect in December 2017, and its legality was upheld by the U.S. Supreme Court on June 26, 2018.

4 At the time of this writing, a crisis has developed along the U.S.-Mexico border based on a zero-tolerance policy that requires children to be separated from their parents who have sought (illegal) entry to the United States, including some who may be seeking asylum but who did not cross the border at a designated port of entry.

\section{Deferred Action for Childhood Arrivals}

${ }^{6}$ Statement made by Pres. Trump at a rally for Alabama Senatorial candidate Luther Strange on September 22, 2017.

Bradley, Deborah. 2018. Artistic citizenship: Escaping the violence of the normative(?) Action, Criticism, and Theory for Music Education 17 (2): 71-91. doi:10.22176/act17.2.71 
7 As implied in the title of the Elliott, Silverman, \& Bowman (2016) book, Artistic Citizenship: Artistry, Social responsibility, and Ethical Praxis. It bears mention that the term social responsibility is not defined for readers in the book.

8 On Jan. 31, 2018, the Canadian Senate passed a bill to make the lyrics of "O Canada" gender neutral (Tasker 2018) by changing the line "all thy sons command" to "all of us command," which coincidentally are the same lyrics I have sung since immigrating to Canada in 1979.

Bradley, Deborah. 2018. Artistic citizenship: Escaping the violence of the normative(?) Action, Criticism, and Theory for Music Education 17 (2): 71-91. doi:10.22176/act17.2.71 